
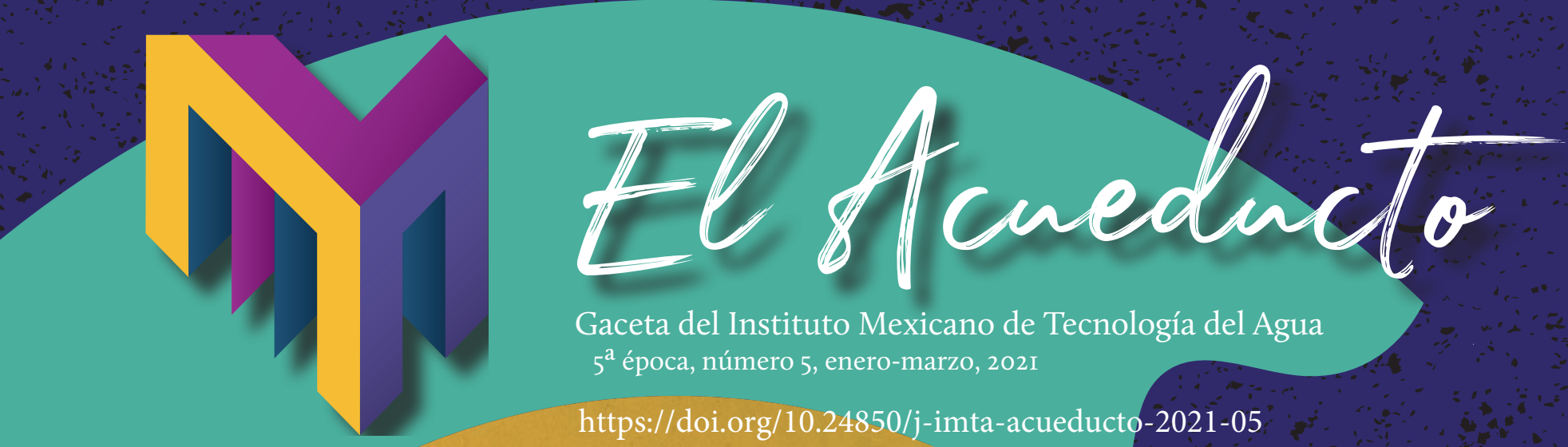

Gaceta del Instituto Mexicano de Tecnología del Agua $5^{\mathrm{a}}$ época, número 5, enero-marzo, 202I

https://doi.org/10.24850/j-imta-acueducto-2021-05

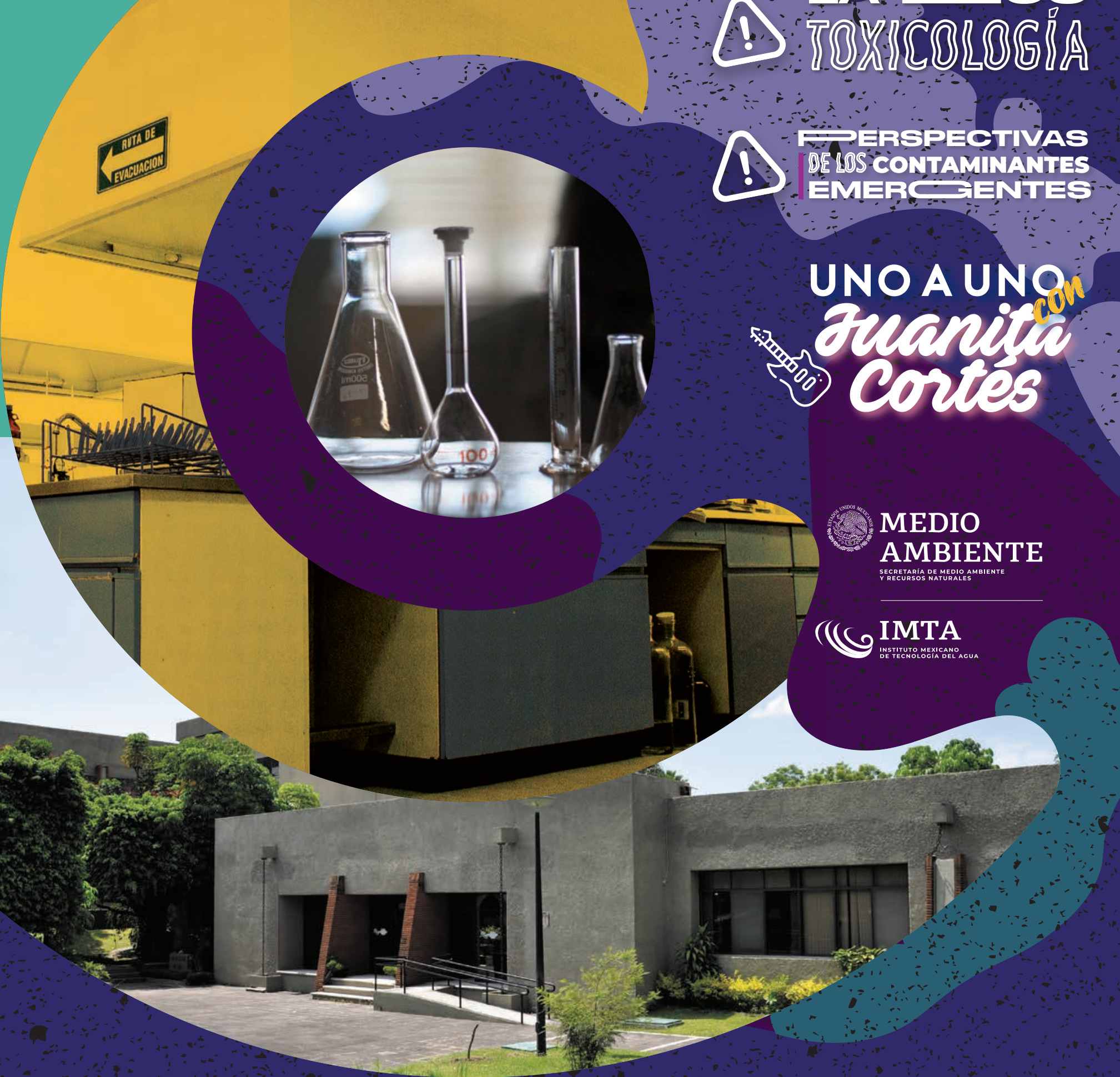




\section{Mensaje del director general}

Estimada comunidad IMTA:

Comienza este segundo año de la segunda época de nuestro Acueducto con la llama de esperanza que ha traído consigo el Programa Nacional de Vacunación, anunciando el principio del fin de la pandemia de COVID-19 en México. A nombre del Instituto, manifiesto nuestra solidaridad y acompañamiento en la pena que embarga a familiares y amigos de nuestras compañeras que se nos adelantaron: Socorro Salazar Orihuela y Yadira Peña Montiel, y hago votos para que los miembros de nuestra comunidad que han perdido a un ser querido encuentren una pronta resignación. Estas situaciones complicadas nos han permitido ver con mucha claridad la gran reserva de valores morales y humanos que tenemos como comunidad y que se reflejan en la solidaridad y cariño expresados.

En otro orden de ideas, quiero compartir con ustedes que, en diciembre de 2020, el Parlamento Latinoamericano y Caribeño aprobó la Ley Modelo de Sistemas Comunitarios de Agua y Saneamiento, la cual ayudamos a diseñar. Lo anterior se logró mediante un trabajo colaborativo con la Amexcid y FAO Mesoamérica, mismo que contó con la confianza de nuestras parlamentarias Dolores Padierna y Ana Lilia Rivera, así como la del diputado Diego del Bosque, y que pone a México a la vanguardia internacional, mostrando las nuevas formas de generar política pública.

Por otra parte, el rol del Instituto como proveedor de evidencia científica en beneficio de la sociedad es cada vez más evidente, como constata nuestra participación dentro del Plan de Justicia para el Pueblo Yaqui. De la mano de la Semarnat y del Instituto Nacional de los Pueblos Indígenas, participamos para atender preocupaciones del pueblo yaqui relativas a la calidad del agua potable, la salinización de suelos en el Distrito de Riego 018 y la rehabilitación del río Yaqui. Esto nos ratifica como la inteligencia hídrica de México, con una ética de servicio a la sociedad, que utiliza el conocimiento e información para construir acuerdos y tejer alianzas que benefician a todos los mexicanos.

En este número leerán sobre la atención que hemos dado a temas novedosos y relevantes, como los contaminantes emergentes y la ecotoxicología. Y en nuestra sección invitada, "Perspectivas", el subsecretario de Planeación y Política Ambiental de la Semarnat, Arturo Argueta Villamar, nos presenta una reflexión detonada por el Día Mundial del Agua.

Los conmino a seguir haciendo la diferencia con entusiasmo y optimismo en nuestro quehacer diario para seguir siendo un motor importante de la transformación del sector hídrico nacional
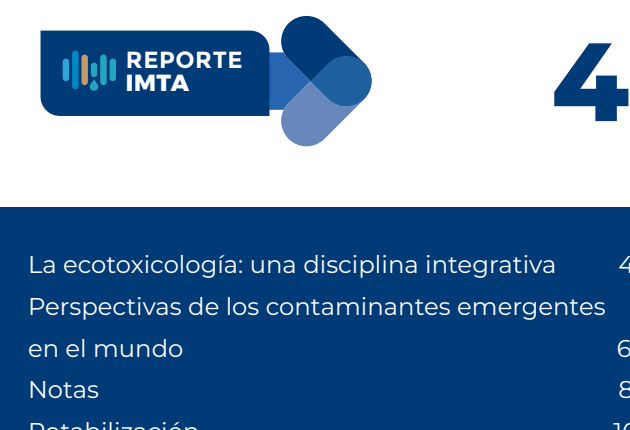

Potabilización 6 8 10

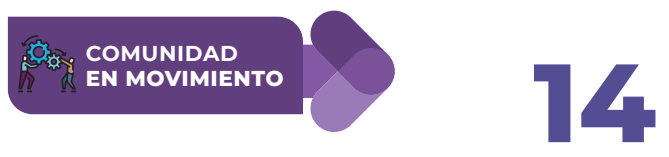

Perspectivas

Uno a uno con Juanita Cortés Mejía

Eventos

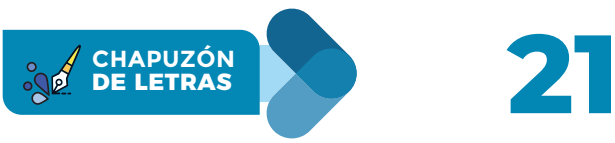

El redactor

Adrián Pedrozo Acuña Director general 


\section{DIRECTORIO}

Director general: Adrián Pedrozo Acuña. Coordinadora de Tratamiento y Calidad del Agua: Norma Ramírez Salinas. Coordinador de Hidrología: José Agustín Breña Naranjo. Coordinador de Hidráulica: Laurent Guillaume Courty. Coordinador de Desarrollo Profesional e Institucional: Alberto Rojas Rueda. Encargado de la Coordinación de Riego y Drenaje: José Antonio Quevedo Tiznado. Encargado de la Coordinación de Comunicación, Participación e Información: Marco Antonio Sánchez Izquierdo. Coordinador de Administración: José de Jesús Aguirre Bautista. Coordinadora de asesores: Malinali Domínguez Mares. Jefe de la Unidad Jurídica: Carlos Eduardo Solórzano López. Titular del Órgano Interno de Control: Omar González Balbuena.

El Acueducto. Gaceta del Instituto Mexicano de Tecnología del Agua, 5 a época, número 5, eneromarzo, 202I.

Publicación trimestral, de distribución interna, editada por la Coordinación de Comunicación, Participación e Información; Subcoordinación de Vinculación, Comercialización y Servicios Editoriales.

Coordinador editorial: Marco Antonio Sánchez lzquierdo. Editor responsable: Emilio García Díaz. Apoyo secretarial: Verónica Jacobo Blancas. Investigación y redacción: Emilio García Díaz, Jesús Hernández Sánchez y Mónica Paulina Gutiérrez Jiménez. Cuidado de edición: Emilio García Díaz y Jesús Hernández Sánchez. Fotografía: Mónica Paulina Gutiérrez Jiménez. Coordinación gráfica: Marianella Espinosa Lara. Diseño gráfico y formación: Adolfo Remigio Armillas, César Plácido Malvaez Doroteo, Cinthya Berenice Uribe Osorio, Gloria Mary Carmen Ríos Beltrán, Mitzi Alejandra Estrada Román, Paola Olmedo Lara, Valeria Richter Soriano y Ana Lilia Torres Garcia. Diseño del logotipo: Valeria Richter Soriano y Paola Olmedo Lara. Versión digital: Claudia Martínez Salgado. Distribución: Luz del Carmen Zavala Vázquez. Oficina de redacción: Edificio i6 "Casa Editorial”. Extensiones 309, 254 y 616. Aportes y sugerencias: redaccionacueducto@tlaloc.imta. $\mathrm{mx}$.

Instituto Mexicano de Tecnología del Agua Paseo Cuauhnáhuac 8532, Progreso, Jiutepec, Morelos, MÉXICO

C.P. 62550. Teléfono: 7773293600.

Impresa en los talleres de Impresión y Diseño.

Nuestra portada: Infraestructura de Calidad del Agua. Diseño: César Plácido Malvaez Doroteo, Cinthya Berenice Uribe Osorio.

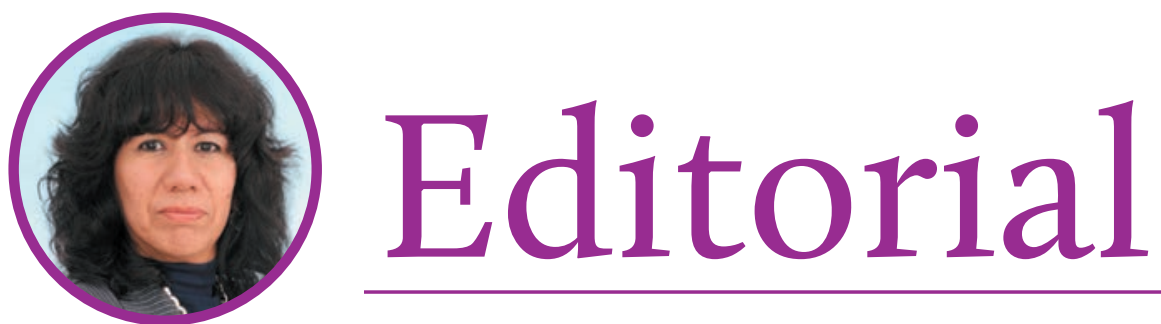

El 2020 fue un año complicado, con incertidumbre, angustia y tristeza por la pérdida de un familiar, amigo o compañero, pero también con enseñanzas y logros que nos han permitido crecer y fortalecernos como seres humanos, tener otra perspectiva de la vida y de la problemática ambiental existente $y$, sobre todo, entender la importancia y responsabilidad que tenemos en la mejora de nuestro medio ambiente.

En este número hablaremos de la ecotoxicología, que es una disciplina integrativa que ayuda a la protección de los ecosistemas y que, si bien sigue siendo apenas una aproximación a la complejidad natural real, nos proporciona información que nos permite avanzar hacia la evaluación de riesgo ambiental, con la que se puede direccionar la regulación del uso de sustancias químicas liberadas en el ambiente.

Existen millones de sustancias químicas que contribuyen significativamente a la degradación del ambiente, entre las que se encuentran los contaminantes emergentes. La Subcoordinación de Tratamiento de Aguas Residuales ha trabajado en diferentes investigaciones con el objeto incrementar el porcentaje de su remoción mediante una combinación de procesos.

Por otro lado, dada la gran importancia que tiene proveer agua apta para uso y consumo humano, referimos cómo la Subcoordinación de Potabilización trabaja en la adaptación de procesos capaces de potabilizar el agua de calidad compleja a costos razonables y de manera eficiente y reseñamos un dispositivo magnético para la reducción de incrustaciones en los sistemas de conducción de agua.

La creciente problemática en la calidad del agua nos genera la necesidad de tener datos de parámetros clave en tiempo real, por lo que se ha trabajado en diseñar y construir el prototipo de un sistema de monitoreo con seis sensores, el cual es una alternativa de bajo costo para llevar a cabo el monitoreo de la calidad en cuerpos de agua en tiempo real.

Para asegurar la confiabilidad en los resultados que emite el Laboratorio de Calidad del Agua, se tienen pruebas acreditadas, las cuales cumplen con un sistema de gestión de calidad. En este número conoceremos las acciones que se requieren para conservar dicha acreditación.

Para el desarrollo de los proyectos es importante contar con capacidad tecnológica. La Subcoordinación de Potabilización nos plática sobre esta y los trabajos que se realizan.

Por último, agradezco a todos los que conforman la Coordinación de Calidad del Agua por los logros obtenidos en 2020, aun con la situación de la pandemia. Estos son una muestra del compromiso que se tiene para aportar al desarrollo sustentable del país, con base en principios éticos y de calidad técnica y académica.

Norma Ramírez Salinas Coordinadora de Tratamiento y Calidad del Agua 


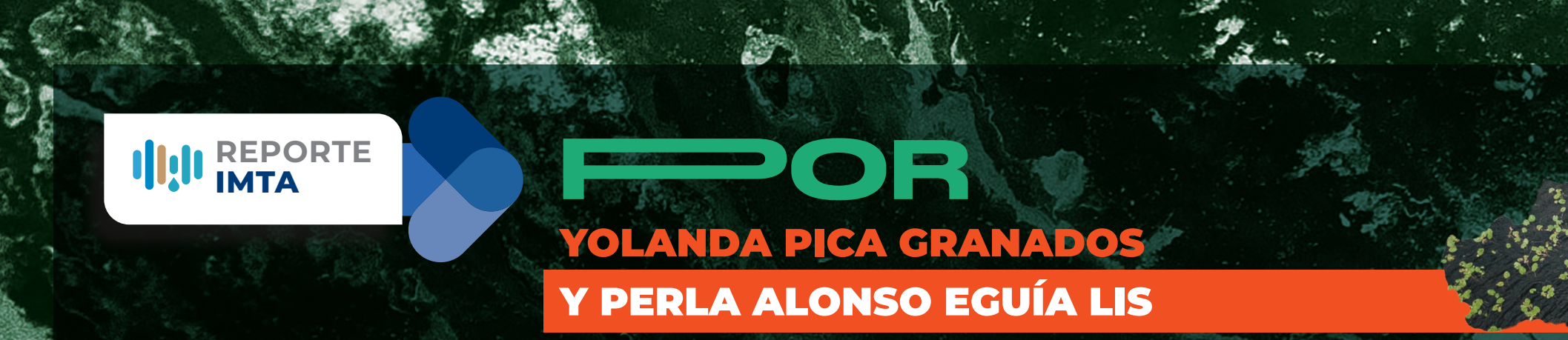

$\mathrm{D}$ esde el inicio de la Revolución Industrial, a finales del siglo XVIII, la sociedad humana no ha dejado de alterar de manera significativa el ambiente en aras de una mejor condición de vida.

Posteriormente, el desarrollo de la ingeniería química generó una enorme cantidad de productos industriales y farmacéuticos no solo de origen natural, sino de nuevas moléculas sintéticas cuyo número se estima en más I70 millones, de las cuales se tiene información toxicológica de alrededor de 100,000 a pesar de que actualmente son 3 i2,000 las sustancias de uso regular, y su número sigue en aumento. Estas moléculas, al ser incorporadas a la intrincada red de procesos naturales que involucra fenómenos físicos, químicos y biológicos, han impactado de manera incalculable ambientes acuáticos (tanto dulces como marinos), terrestres y atmosféricos.

El estudio de los efectos de los contaminantes a través de los diferentes niveles de organización biológica determina el campo de trabajo entre la toxicología y la ecotoxicología, en donde la complejidad no solo es estructural, sino también espacio-temporal.

La toxicología es una ciencia experimental, basada en la comprensión de los efectos directos asociados con la exposición, realizada en laboratorios bajo variables controladas. Esta mide las respuestas o efectos a dos niveles: a nivel celular, a través del daño en el DNA, taza de respiración y alteraciones metabólicas, y a nivel de individuo, donde las respuestas son mortalidad (como el conocido $\mathrm{LC}_{5} 0$ que es la concentración a la cual el $50 \%$ de la población control muere en un periodo determinado), crecimiento, reproducción y comportamiento.
Cuando los estudios se llevan a cabo sobre poblaciones (individuos de la misma especie), comunidades (conjunto de poblaciones de distintas especies que interactúan en tiempo y espacio) y ecosistemas, estamos entrando en el terreno de la ecotoxicología, en donde las relaciones entre los factores no controlados abióticos y bióticos, como son las interacciones biológicas (p. ej. redes tróficas) y sus respuestas a la contaminación, conducen a una complejidad mucho mayor $y$, por ende, su interpretación es igualmente complicada.

Las respuestas a la contaminación a nivel población se traducen en cambios en la proporción de sexos, estructura genética y estructura de edades. En las comunidades, los efectos se pueden medir en efectos directos, como la pérdida de especies sensibles o reducción de número
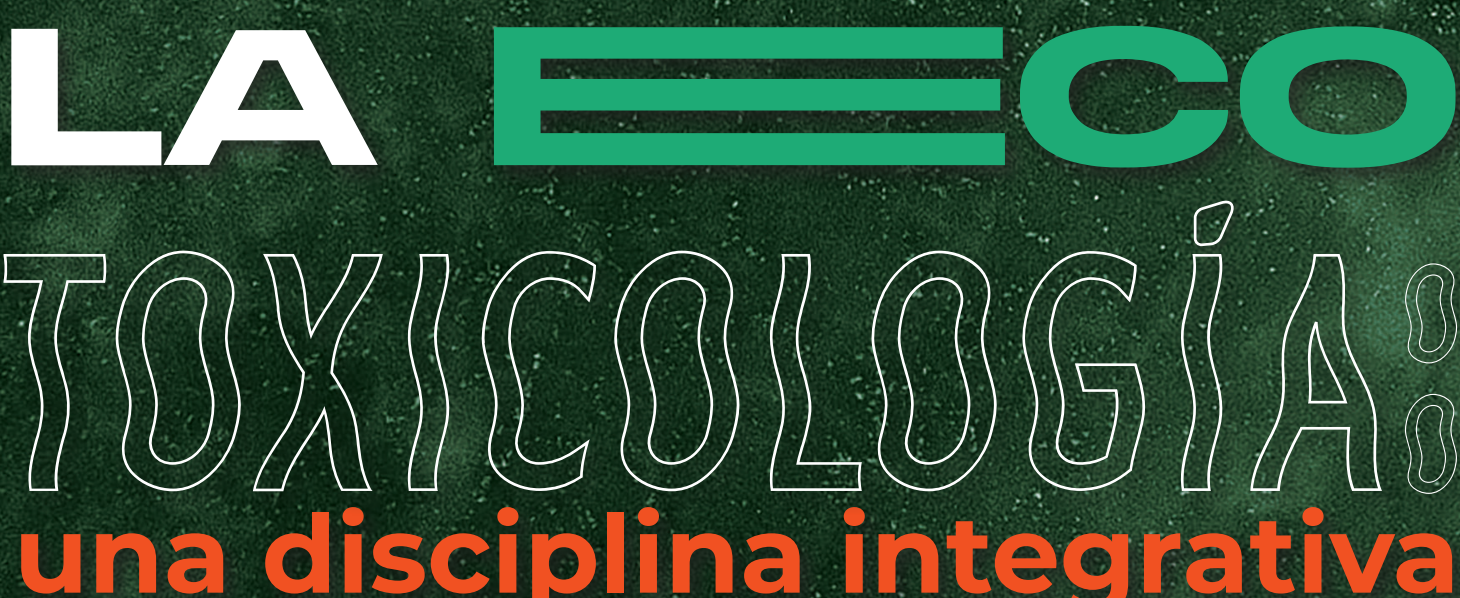

0

$\therefore: 0^{3}$

3.

2.

$=0$

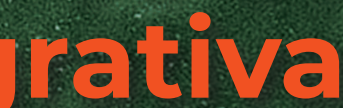

\section{PARA LA PROTECCIÓN}

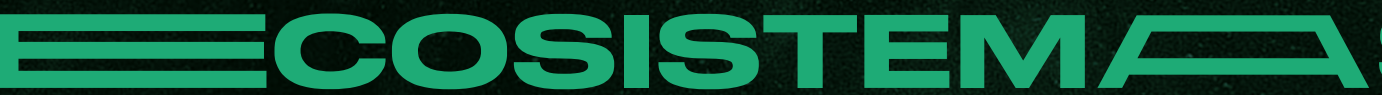







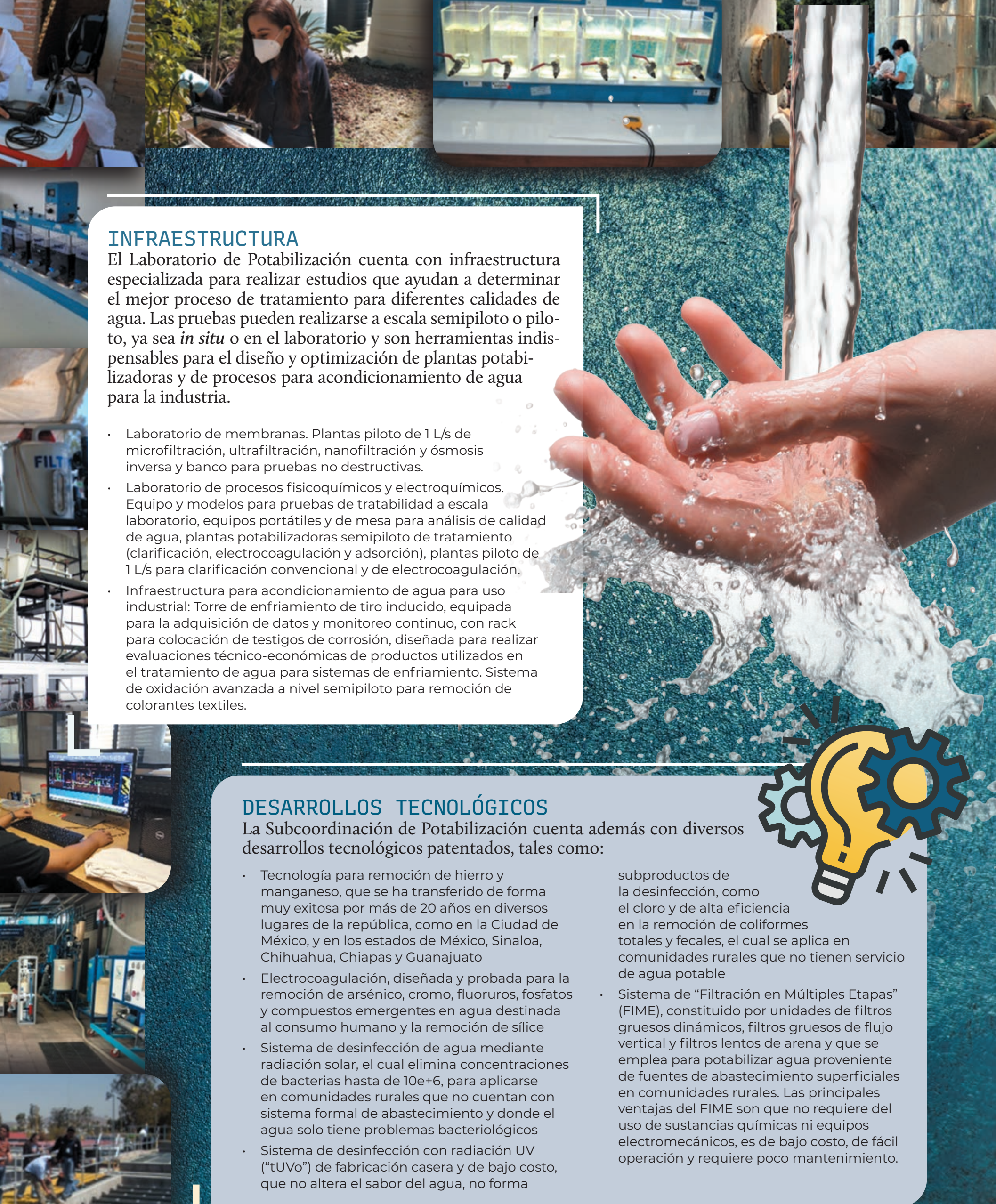



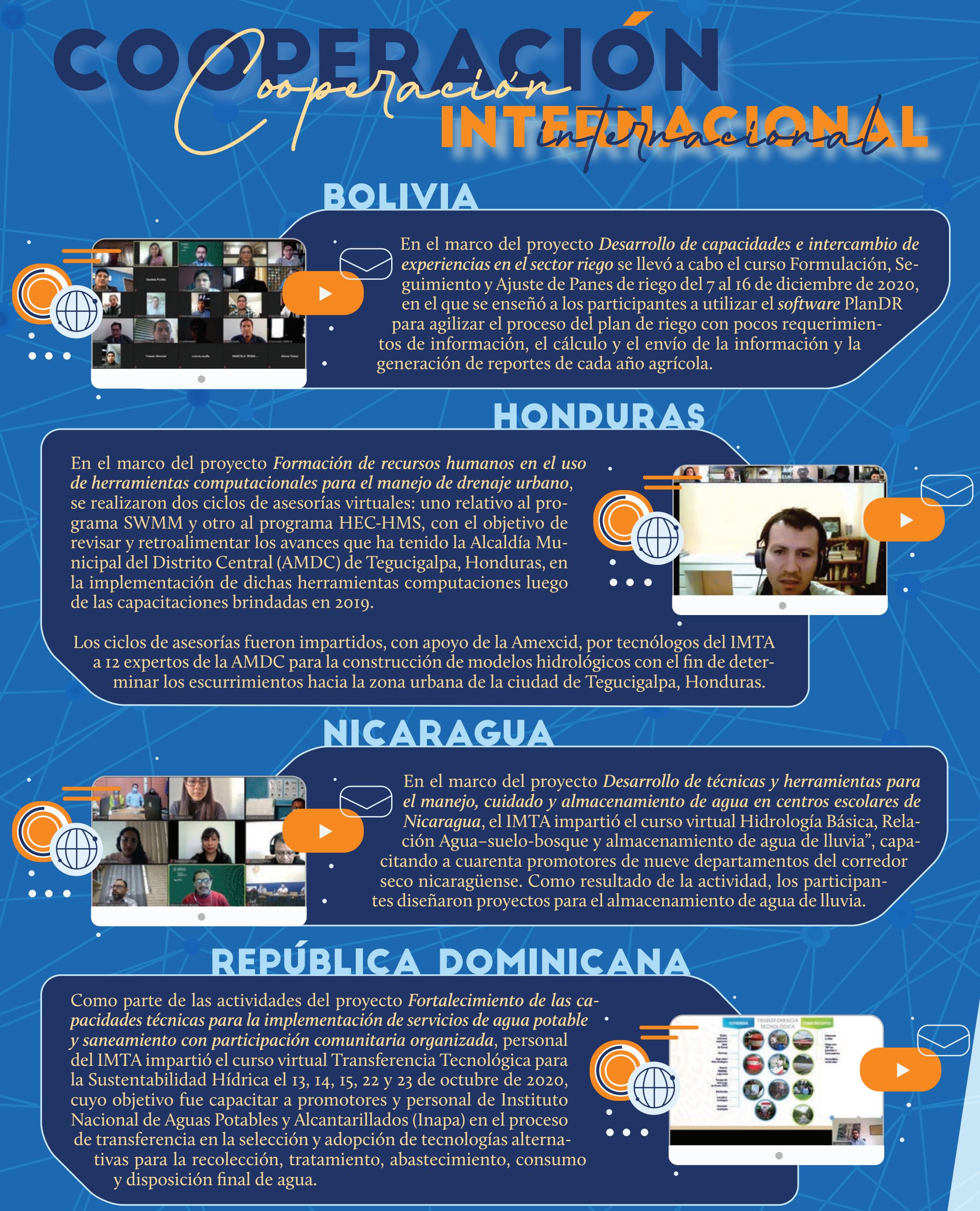


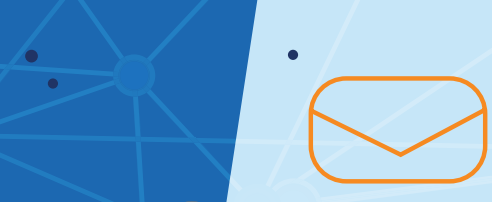

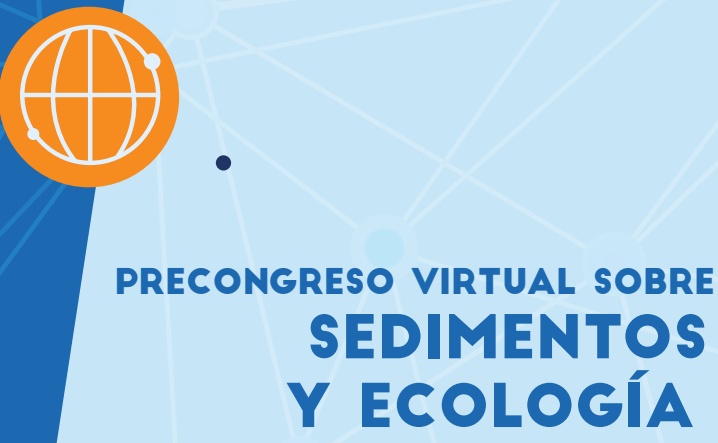

Como parte de las actividades previas al III Congreso Iberoamericano sobre Sedimentos y Ecología, el 25 de noviembre se realizó un precongreso virtual en colaboración con la ISI para América Latina y el Caribe (ISI-LAC) y el Instituto Mexicano de Tecnología del Agua.

Entre los temas de erosión, sedimentos y ecología, el rol de los glaciares en la generación de sedimentos, aplicaciones de la ecohidrología en la gestión de recursos hídricos y problemática, monitoreo y perspectivas a futuro.

Las actividades surgen de la Iniciativa Internacional de Sedimentos (ISI) de la Organización de las $\mathrm{Na-}$ ciones Unidas para la Educación, Ciencia y Cultura (Unesco) y aborda temas tanto de cantidad como de calidad de sedimentos, tomando en cuenta el cambio global.

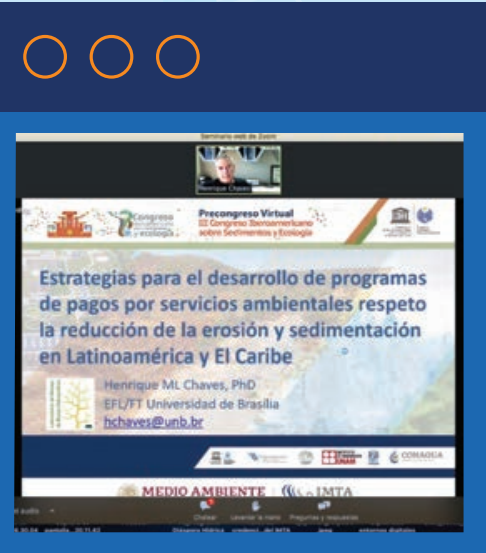

\section{PARTICIPACIÓN EN LA PROPUESTA PARA LEY MODELO DE SISTEMAS COMUNITARIOS DE AGUA Y SANEAMIENTO}

\section{Autoridades mexicanas presenta-} ron al Parlamento Latinoamericano y Caribeño (Parlatino) los avances del borrador de la propuesta de Ley Modelo de Sistemas Comunitarios de Agua y Saneamiento, que servirá como base para brindar a los países de la región un marco jurídico y técnico encaminado al logro de los derechos humanos al agua y al saneamiento, particularmente en las comunidades rurales y periurbanas, que permita sumar los esfuerzos de la sociedad y los gobiernos para ampliar la cobertura y la calidad de estos servicios en regiones donde estas son insuficientes.

La propuesta es resultado del esfuerzo conjunto del Frente Parlamentario contra el Hambre, Capítulo México (FPH), la Secretaría del Medio Ambiente y Recursos Naturales (Semarnat), a través del IMTA, la Agencia Mexicana de Cooperación Internacional para el Desarrollo (Amexcid), el propio Parlatino y la FAO en el marco del programa Mesoamérica sin Hambre, que, entre otras acciones promueve el diálogo político de alto nivel para impulsar la seguridad alimentaria y el desarrollo rural.

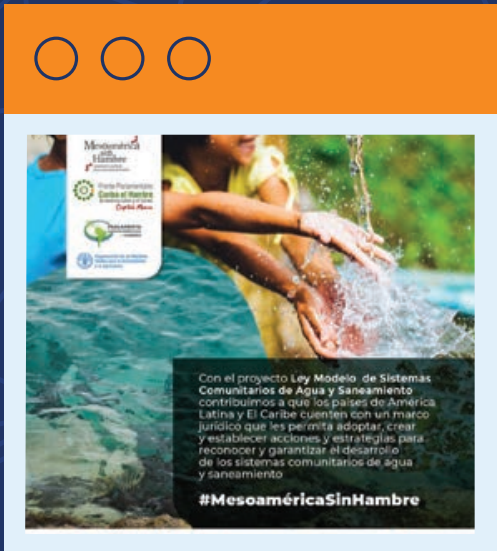

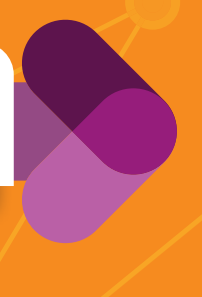

MIEMBROS DEL IMTA EN EL SNI

En la convocatoria 2020 del Sistema Nacional de Investigadores, diez miembros del IMTA ascendieron o permanecieron en este grupo de profesionistas.

\section{Enhorabuena por su perse-} verancia y constancia en su preparación para aportar el conocimiento que permite hacer del agua un elemento de equidad y bienestar para los mexicanos con un enfoque sostenible. 


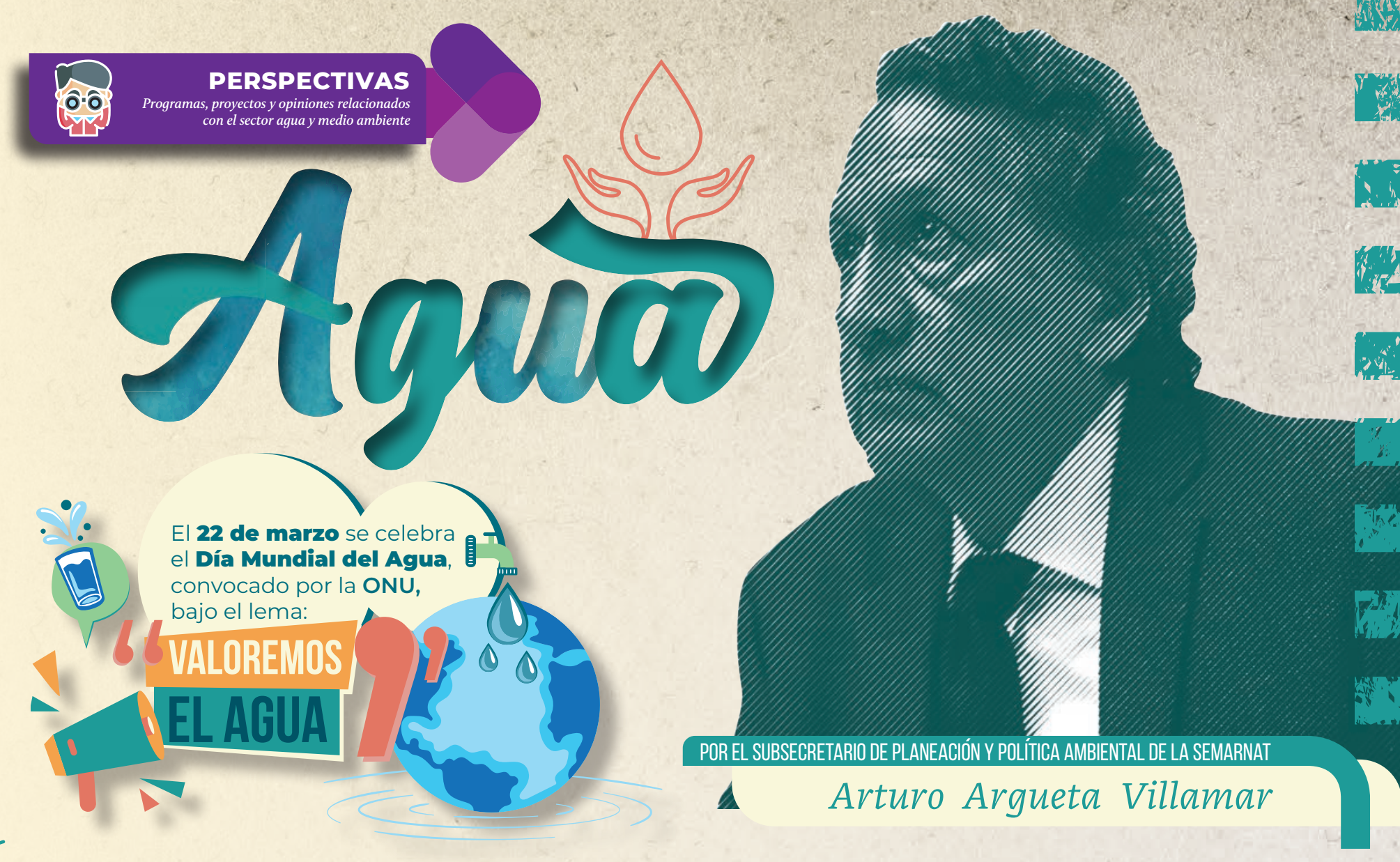

Esta misma organización ha lanzado la iniciativa del Decenio del Agua (2018-2028) para reforzar la reflexión sobre la importancia del agua en nuestras vidas. La pandemia de COVID-I9 nos ha enseñado (la cruel pedagogía del virus, la llama Boaventura Sousa Santos) que no hay resquicio para la duda: el lavado de manos con agua y jabón es una gran línea de defensa contra el contagio.

El sexto objetivo de desarrollo sostenible propone que haya "Agua y saneamiento para todos en el 2030", lo cual constituye un enorme reto para cada uno de los países del planeta, dado que una de cada tres personas no tiene acceso al agua potable para lavarse las manos contra el coronavirus y otros muchos agentes de enfermedades infectocontagiosas.

El agua es indispensable para mantener la salud humana, pues es un componente mayoritario (entre 80 y $90 \%$ ) de la sangre humana. En cantidades similares, no menores al $70 \%$, se le encuentra en la piel, los riñones, los pulmones, los músculos y el cerebro. Las autoridades de salud recomiendan no tomar ni poca ni mucha: tomar poca deshidrata y daña los órganos, pero tomar mucha también tiene efectos adversos, por ejemplo, sobre los músculos, al producir un déficit de potasio o al provocar una mala digestión. Una buena cifra se obtiene si multiplicamos nuestro peso corporal por 30 mililitros, cantidad que incluirá no solo agua pura, sino también la que tomamos en caldos, sopas, jugos naturales, verduras y frutas.

Una paradoja de nuestros tiempos es que hidratar y mantener sanos nuestros cuerpos se ha traducido en una enorme enfermedad para el planeta, porque el consumo de agua en botellas de plástico ha propiciado que hoy se les encuentre en caminos, basureros, ríos, presas, costas y mares; formando incluso parte de las enormes islas de plásticos que flotan en los océanos.

Este año, la ONU nos convoca a "valorar el agua", a meditar sobre su verdadero valor, desde distintas perspectivas y experiencias humanas. La forma y grado en que la valoremos determinará la manera en que la utilicemos y compartamos. Y en este punto es donde se establece una controversia entre quienes consideran el agua como un bien comercial y quienes sostienen que se trata de un bien social, ligado indisolublemente al derecho a la vida.

De acuerdo con el Programa de las Naciones Unidas para el Medio Ambiente, América del Sur es la región que cuenta con la mayor porción de agua dulce del mundo en la cuenca amazónica y sus grandes afluentes. El dato es de enorme importancia geo- y biopolítica, ya que solamente el $2.5 \%$ del agua es apta para el consumo humano y las actividades productivas, mientras que el $97.5 \%$ restante es salada.

El llamado de la ONU es a que reflexionemos sobre los múltiples significados que tiene el agua para todos los seres humanos. Pensemos en situaciones críticas por su 
carencia: deshidratación, pérdida de cobertura vegetal, muerte de plantas y animales, pérdida de biodiversidad, - erosión y degradación del suelo y, finalmente, desertificación en sus diversos procesos y grados.

Seguramente la mayoría de ustedes recordarán al pequeño príncipe que se hace presente ante un aviador cuya nave cae en el desierto del Sahara y que le hace preguntas trascendentales y lo acompaña mientras repara su avión en la formidable historia de $E l$ Principito, de Antoine de Saint Exupéry. Pero quizá no sepan que, en la vida real, Saint Exupéry fue primero piloto de guerra, después piloto civil y nuevamente piloto de guerra durante la Segunda Guerra Mundial. Mientras estuvo desempeñándose como piloto civil, efectivamente cayó su avión en el desierto del Sahara, en la porción del mismo en Libia. Él y su copiloto, André Prévot, salieron ilesos de la caída, pero al hacer inventario de sus recursos, vieron que contaban tan solo con un pequeño racimo de uvas, una naranja, un cuarto de botella de vino blanco y medio litro de café; ningún alimento sólido, ninguna fuente de agua en kilómetros alrededor. Sabían que esas reservas se acabarían en cinco horas de caminata, y que podrían morir por deshidratación en alrededor de ig horas, según el manual de pilotos que sobrevolaban el Sahara. Caminaron muchos kilómetros, intentaron cosechar agua del rocío, pelearon y lloraron, y conocieron a los zorritos orejones, llamados fenecos, uno de los cuales le pide al principito que lo domestique. Resistieron más de ocho días, pero el final no lo voy a contar...

La historia de ese drama la narra en su libro Tierra de hombres, publicado cuatro años después de la tragedia y algunos antes de El Principito (1943), pero lo más importante para el tema que nos ocupa hoy es el pasaje de lo que yo llamaría su: oda al agua. Quienes han estado privados del agua, racionados de la misma, al punto de la muerte, pueden enseñarnos mucho sobre cómo revalorar y reapreciar el agua con otros ojos, de otros modos, quizá como aconseja el zorro al principito: "con el corazón, ya que lo esencial es invisible a los ojos", y por supuesto, con estas otras palabras:

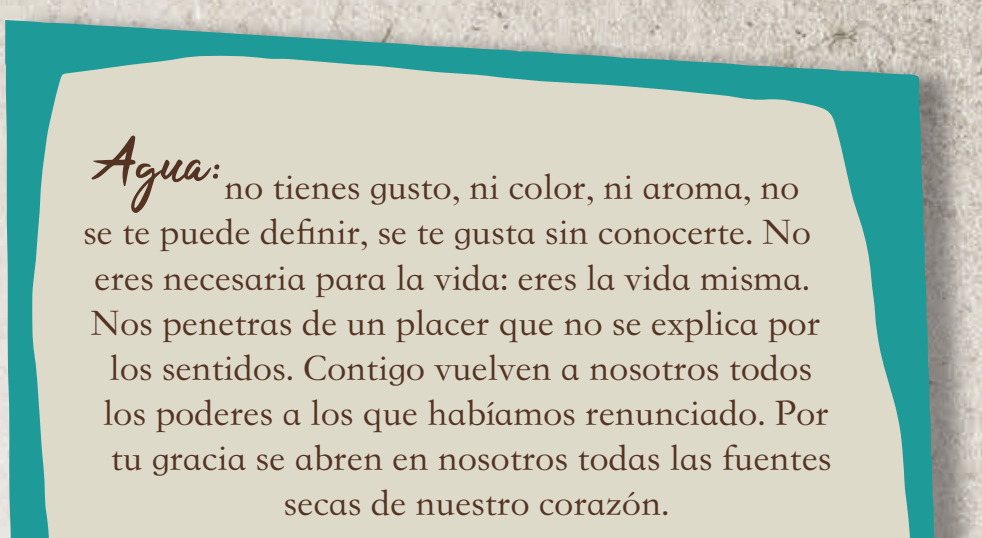

Eres la mayor riqueza que puede haber en el mundo, y eres también la más delicada, tú, tan pura en el vientre de la tierra. Se puede morir sobre una fuente de agua magnesiada. Se puede morir a dos pasos de un lago salado. Se puede morir a pesar de dos litros de rocío que contienen, en suspensión, algunas sales.

No aceptas mezclas, no soportas alteración, eres una espantadiza divinidad... Pero difundes en nosotros una dicha

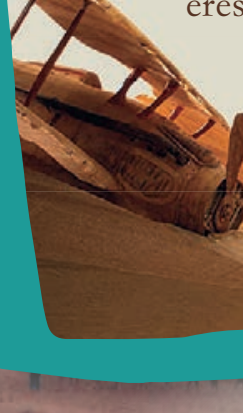

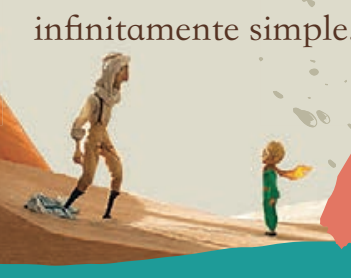

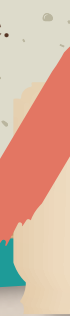

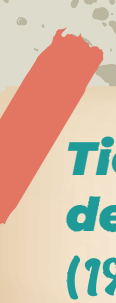

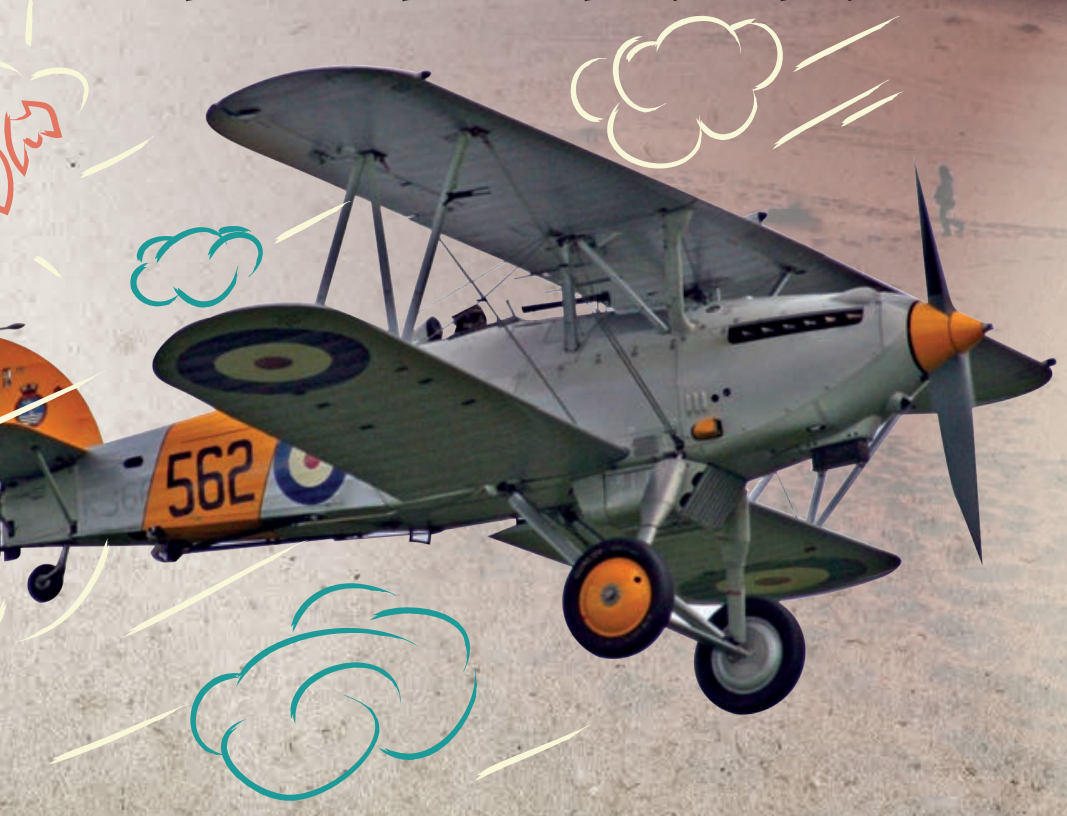

Creo que la expresión "Sin agua no hay bosques, sin bosques no hay vida" es muy valiosa, y como el próximo $2 \mathrm{I}$ de marzo es el Día Internacional de los Bosques, vaya con estas palabras un emocionado homenaje al agua y los bosques, así como a todas las personas que dedican sus esfuerzos a esos preciosos legados, eternos inseparables. Y hablando de bosques, en octubre de 202I llevaremos a cabo el Festival Nacional por el Agua y los Bosques. Por una Cultura del Cuidado de la Vida, al cual estamos haciendo una invitación muy amplia a participar, por parte de los convocantes: la Universidad Nacional Autónoma de México y todo el sector ambiental del Gobierno de México. 


\section{de que falta mucho por hacer. Al final vas aprendiendo
y conjuntas experiencias para integrarlas al siguiente proyecto.}

Entre otras actividades, participé en un proyecto en la zona del lago de Chapala, donde estudiamos la relación que existe entre la calidad del agua y la de su pesquería. También he realizado investigación sobre evaluación de programas que tienen que ver con la salud y el ambiente. Mi área siempre ha sido la salud del ambiente y su relación con la salud pública. Soy antropocéntrica, jamás lo he negado.

He trabajado también en el tema de contaminantes emergentes y su relevancia en los esquemas de reúso para agua potable. Colaboré con las personas de aguas residuales, potabilización y calidad del agua en la revisión de fármacos y otros compuestos orgánicos que se pueden encontrar en el agua con el propósito de encontrar la forma de darle un tratamiento que mejore su calidad y pueda destinarse a diferentes usos, incluido el potable. En un futuro no muy lejano encontrar agua de primer uso será complicado.

Al final, sí hay soluciones. Somos ciento veintiséis millones de habitantes en México, y es importante que todos pongamos un granito de arena en la medida que nos toca. Si cada persona, institución y gobierno hacen su parte se puede aliviar muchísimo la contaminación de todo tipo.

El Acueducto: Atendiendo tu experiencia en epidemiología y ubicándonos en el contexto actual, dominado por la pandemia que ahora nos aqueja, sabemos que también este virus nos ha enseñado algunas cosas sobre nuestra relación con la salud del planeta. ¿Qué nos puedes compartir al respecto?

auanita: Los coronavirus, como familia, existen desde siempre, lo que pasa ahora es que sufrieron una mutación que no conocemos exactamente, por lo que el desarrollo de una vacuna ha sido muy complicado. Por ejemplo, para el cólera jamás se encontró una vacuna realmente confiable, porque el virus que lo causa tiene una memoria muy pequeña.

Una de las experiencias que me dejó mucho, tanto en lo personal como en lo profesional, fue haber trabajado en el tema del cólera. Esta enfermedad nos dio muchas lecciones que, desgraciadamente, ya se nos olvidaron, como son la adopción estricta de medidas básicas de higiene, relacionadas con la calidad y cantidad de agua disponible.

Ahora sabemos que el cólera es un patógeno reemergente, es decir, estaba controlado, pero resurgió con características similares. También sucede que se presentan brotes de otros patógenos, como los emergentes, que no conocíamos, como es el caso del virus SARSCoV-2, causante de COVID-I9.

\section{El Acueducto: ¿Ahora qué sigue para ti?}

zuanita: Por ahora trabajo en el proyecto del Atlas de calidad del agua, a cargo del Laboratorio de Calidad del Agua.

El Acueducto: Por ahí nos contaron que te gusta la música, platícanos de esa faceta tuya.

zuanita: Ah sí, soy melómana. Me encanta la música, el rock, sobre todo el progresivo, y la música clásica. Mi grupo favorito es King Crimson y adoro a Frank Zappa, el tipo era un visionario, súper crítico, no siempre sencillo.

El Acueducto: ¿Quisieras comentar algo más a nuestros lectores?

auanita: He pasado más de la mitad de mi vida en el Instituto, al que considero como mi otra casa. Quiero mucho a la institución y a las personas que aquí he conocido y que son muy importantes para mí. Me quedo con muchas cosas muy buenas de todos, de muchos compañeros de muchos años.

Hay otros a los que no he tenido la oportunidad de conocer, pero me encantaría. Y, por último, insistirles que lo primordial es que te guste lo que haces, que no lo hagas por obligación, porque si no es muy difícil sobrellevar las circunstancias. Sigamos trabajando en este tema tan importante como el agua, para conservarla y cuidarla.

Es importante saber lo que tú puedes aportar para prevenir, más que corregir, y mantener limpio, más que limpiar el medio ambiente. Soy antropocéntrica porque, nos guste o no, todo gira alrededor del ser humano $y$, por lo tanto, el fin del trabajo que realizamos es buscar el equilibrio entre los diversos factores que intervienen en nuestro entorno: si lo cuidamos nos cuidamos también. 


\section{$25 / 09 / 20$}

Espacio de Conocimiento en Línea

"Remoción de compuestos emergentes en aguas residuales"

Dra. Petia Mijaylova Nacheva

- Instituto Mexicano de

Tecnología del Agua

Seminario Pequeñas Centrales Hidroeléctricas

Miguel Ángel Mejía González - Instituto Mexicano de Tecnología del Agua

Luis González Hita - Instituto Mexicano de Tecnología del Agua
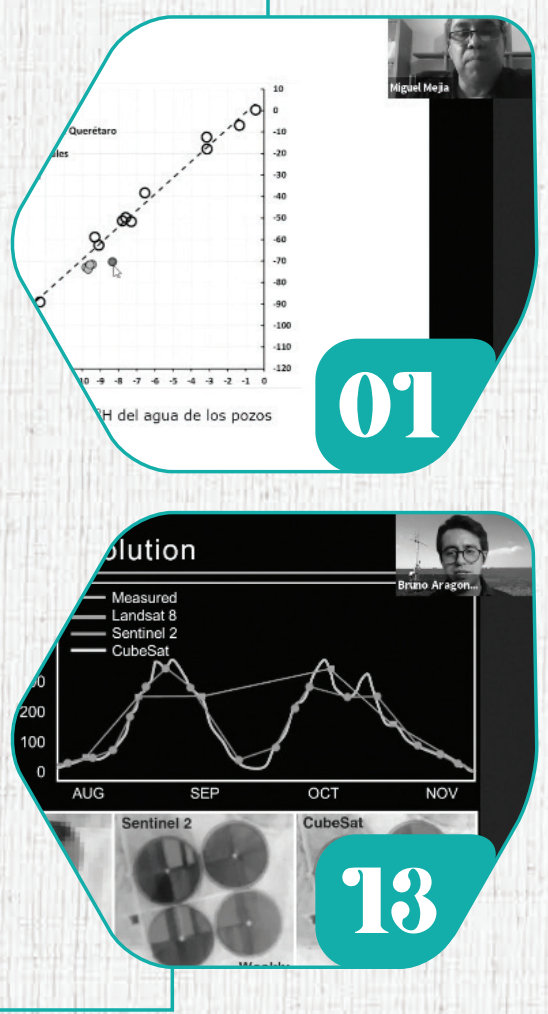

Estimación de Evapotranspiración en Alta Resolución Espaciotemporal

Bruno Aragón - Candidato a Doctor - KAUST, Arabia Saudita.

\section{$03 / 12 / 20$}

18. I ELLACUEDUCTO INERO-MMAkZ

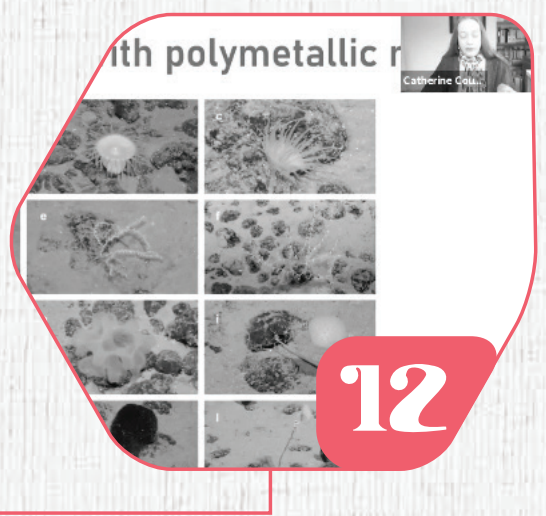

Understanding Global Calls for Moratorium on Deep Seabed Mining: Environmental, Climate Change and Governance Considerations.

Peticiones Globales de una Moratoria a la Minería Submarina Profunda: Consideraciones Ambientales, de Cambio Climático y de Gobernanza

Dra. Catherine Coumans - Coordinadora de investigación y Coordinadora del Programa Asia-Pacífico en MiningWatch, Canadá.

27/11/20

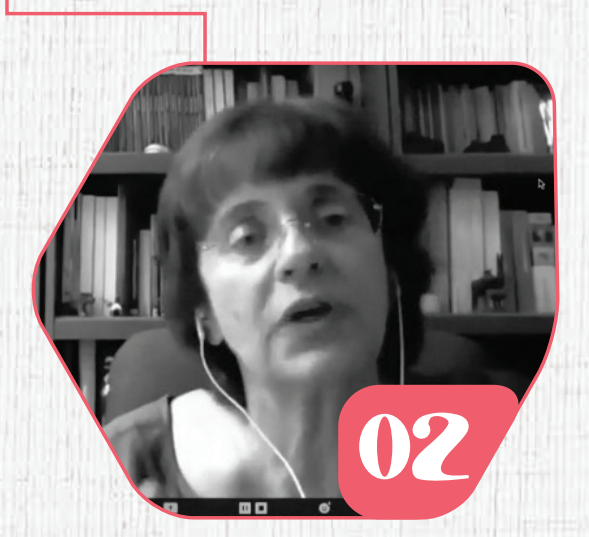

\section{$02 / 10 / 20$}

Espacio de Conocimiento en Línea "Avances en la comprensión y mitigación ante tsunamis. Chile 2010-2020"

Dr. Patricio Catalán, Universidad Federico Santa María, Chile.
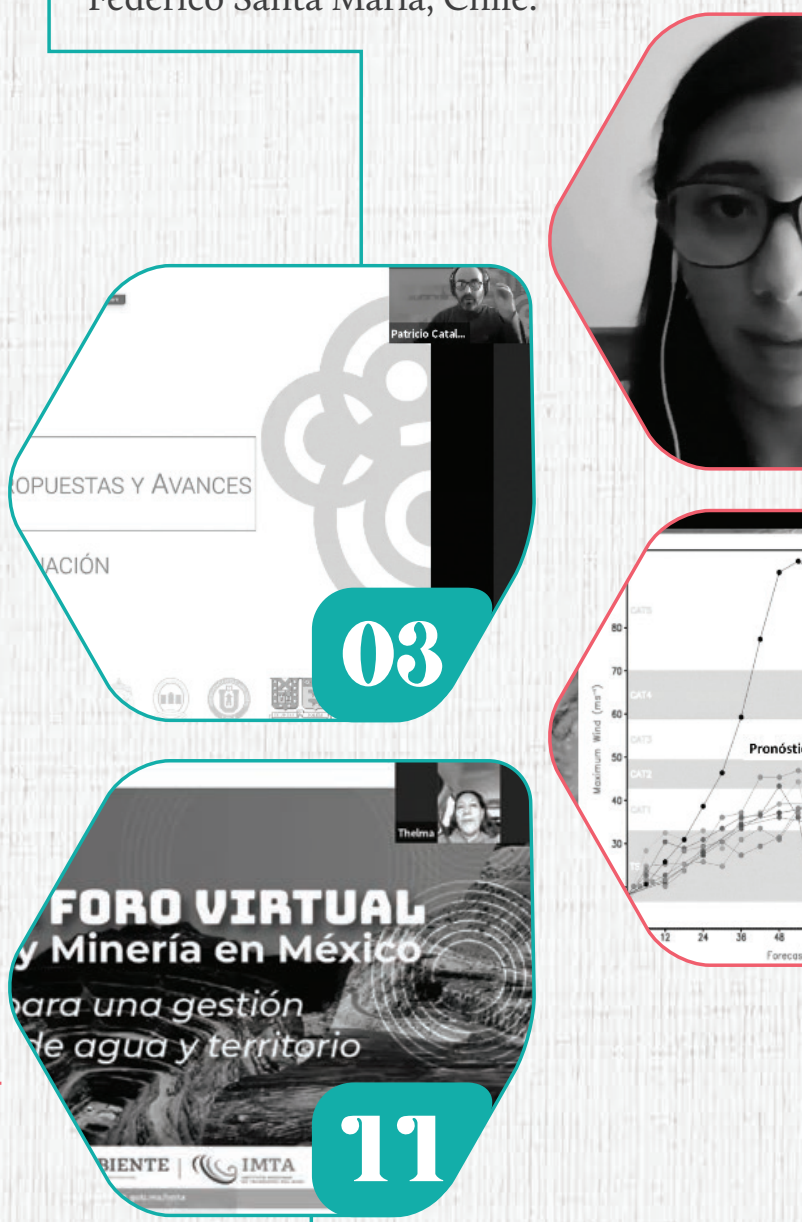

Primer Foro Virtual de Agua y Minería en México: Desafíos para una Gestión Integrada de Agua y Territorio

19/11/20 


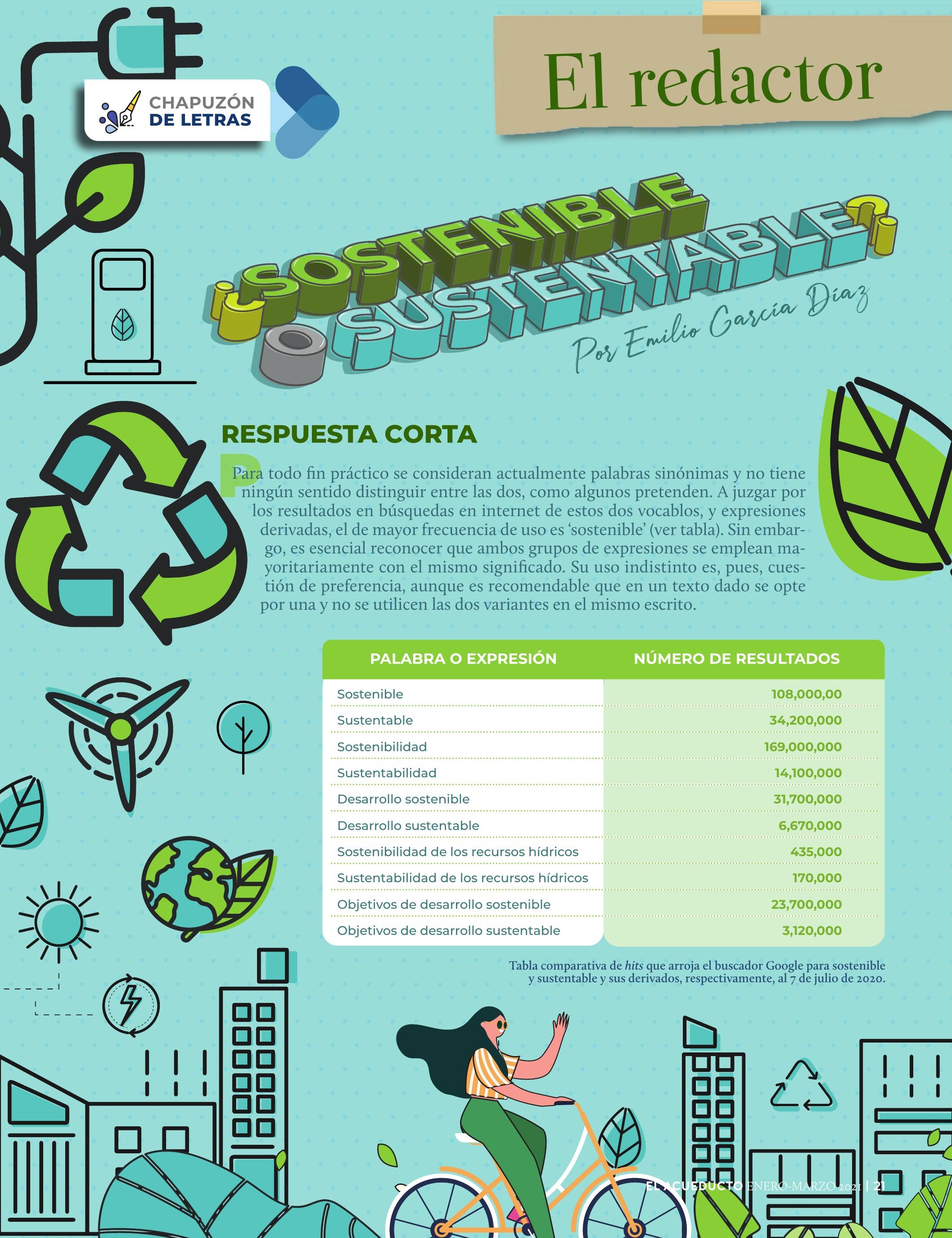




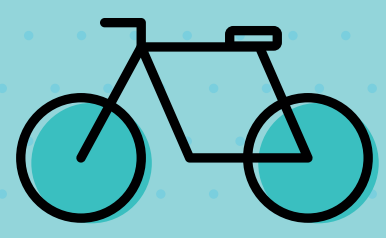

La Fundación del Español Urgente (Fundéu)[I] señala que "para referirse al modelo de desarrollo consciente de la necesidad de no agotar los recursos, son válidos los adjetivos 'sustentable' y 'sostenible'. El adjetivo 'sustentable' se incluye en la vigesimotercera edición del diccionario académico [el DRAE[2]] solo con el significado de 'que se puede sustentar o defender con razones', pero no con el de 'que se puede mantener durante largo tiempo sin agotar los recursos o causar grave daño al medio ambiente', sentido este último de amplio uso sobre todo en el español americano y que coincide con la definición de 'sostenible' de esta misma obra.”[3]

Ahora bien, existen algunos autores que pretenden hacer una distinción, como Plinio Zarta Ávila, quien afirma que "...si bien tienen aristas comunes, lo sustentable hace relación a la armonía existente entre lo económico, lo social, lo ambiental con el sistema de valores, en tanto que lo sostenible considera cada uno de dichos subsistemas por separado" [4]. Tal afirmación carece

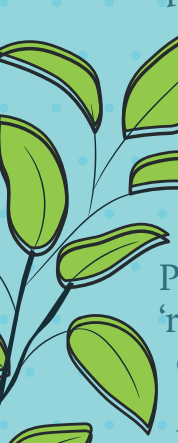

$\Longrightarrow$ de sustento etimológico y semántico y pretende adjudicar un significado que no tienen inherentemente dichas palabras.

Por su parte, Enrique Leff alude a la 'razón' de la definición del DRAE y, en su libro Racionalidad ambiental, sostiene que "...la racionalidad de la sustentabilidad abre la posibilidad de construir un nuevo paradig-

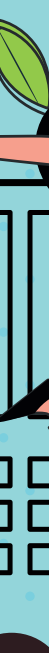
ma productivo..." y que “... los principios de la racionalidad ambiental definen un concepto de productividad sustentable".

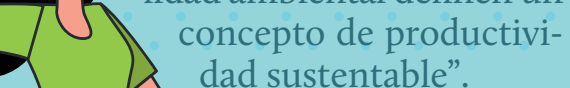

Algunos otros autores discuten sobre cuál de las dos voces que nos ocupan parece ser la más adecuada.

Sin embargo, los lingüistas [5] nos dicen que el origen de ambas es el mismo: el verbo latino sustinēre, que derivó en 'sostener' en español. Sustentāre, de donde viene 'sustentar', no es más que el modo intensivo, llamado también frecuentativo o iterativo [6], de sustinēre, el cual se descompone en sus (desde abajo) y tinere (tener), con el significado de 'asir desde abajo'. Sustentar, como verbo intensivo, significa sostener algo para que no se caiga o tuerza. Con el tiempo, este último verbo adquirió el sentido figurado de "sostener" un argumento con razones para que este no se "caiga" o tergiverse.

Pero, ¿cómo fue que tanto 'sostenible' como 'sustentable' adquirieron la acepción, en los ámbitos de la ecología y la economía, de algo que se puede mantener durante largo tiempo sin agotar los recursos o causar grave daño al medio ambiente?

No fue sino hasta principios de los 8 o que el concepto de sostenible/ sustentable (originalmente en inglés: sustainable) se empezó a utilizar ampliamente entre grupos y ONG ambientalistas y, en I987, se plasmó en el documento Nuestro futuro común (Our Common Future) [7]. Los traductores oficiales de este igualmente llamado Informe Brundtland (IB) eligieron la palabra 'duradero' en español y durable en francés (término que aún se emplea en esa lengua). Posteriormente se optó con mayor frecuencia por usar en español 'sostenible', traducción literal del vocablo original inglés.
Poco a poco fue apareciendo también 'sustentable' por parecerse más, morfológicamente, a sustainable. Finalmente, dado que en 1992 se celebró la Cumbre de la Tierra en Río de Janeiro, Brasil, donde cobró más auge el ya referido IB y se discutió en torno al "desarrollo sostenible", en el país anfitrión se comenzó a hablar y escribir sobre el desenvolvimento sustentável. Nuevamente, por la mayor proximidad léxica con este término portugués, se comenzó a utilizar con mayor frecuencia el adjetivo 'sustentable', sobre todo en el ámbito periodístico, y duradero quedó relegado por completo. De ahí en adelante, los dos términos en cuestión se emplean bien como sinónimos o como preferente el uno del otro con un matiz extraligüístico, dependiendo de las tendencias ideológicas, intereses o concepciones particulares de quien los utiliza.

Cabe señalar que en la Constitución Política de los Estados Unidos Mexicanos, en las reformas más recientes, la palabra 'sustentable' aparece en cinco ocasiones en referencia al desarrollo; una al aprovechamiento de la energía, y una al uso de los recursos hídricos, mientras que 'sostenible' aparece una vez en el contexto del manejo de las finanzas públicas. Este hecho puede ser para algunos un criterio de elección válido, sobre todo en documentos oficiales.

Por otra parte, al hablar de los Objetivos de Desarrollo Sostenible es preferible mantener este término, ya que es el que quedó plasmado oficialmente en este programa de la ONU.

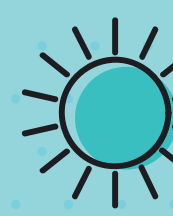

Por lo demás, mientras se atiendan los principios de congruencia, coherencia y homogeneidad, se puede emplear cualquiera de las dos variantes sin incurrir en un error lingüístico o semántico.
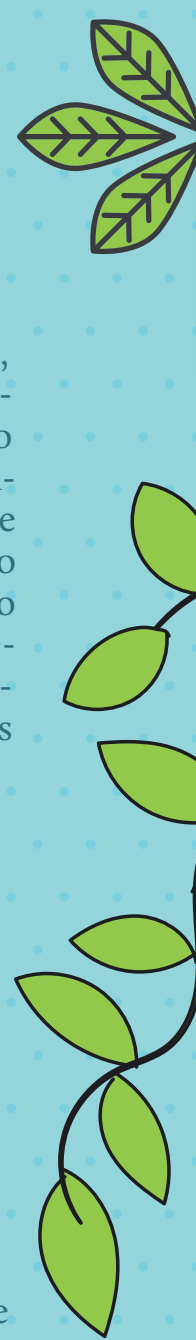



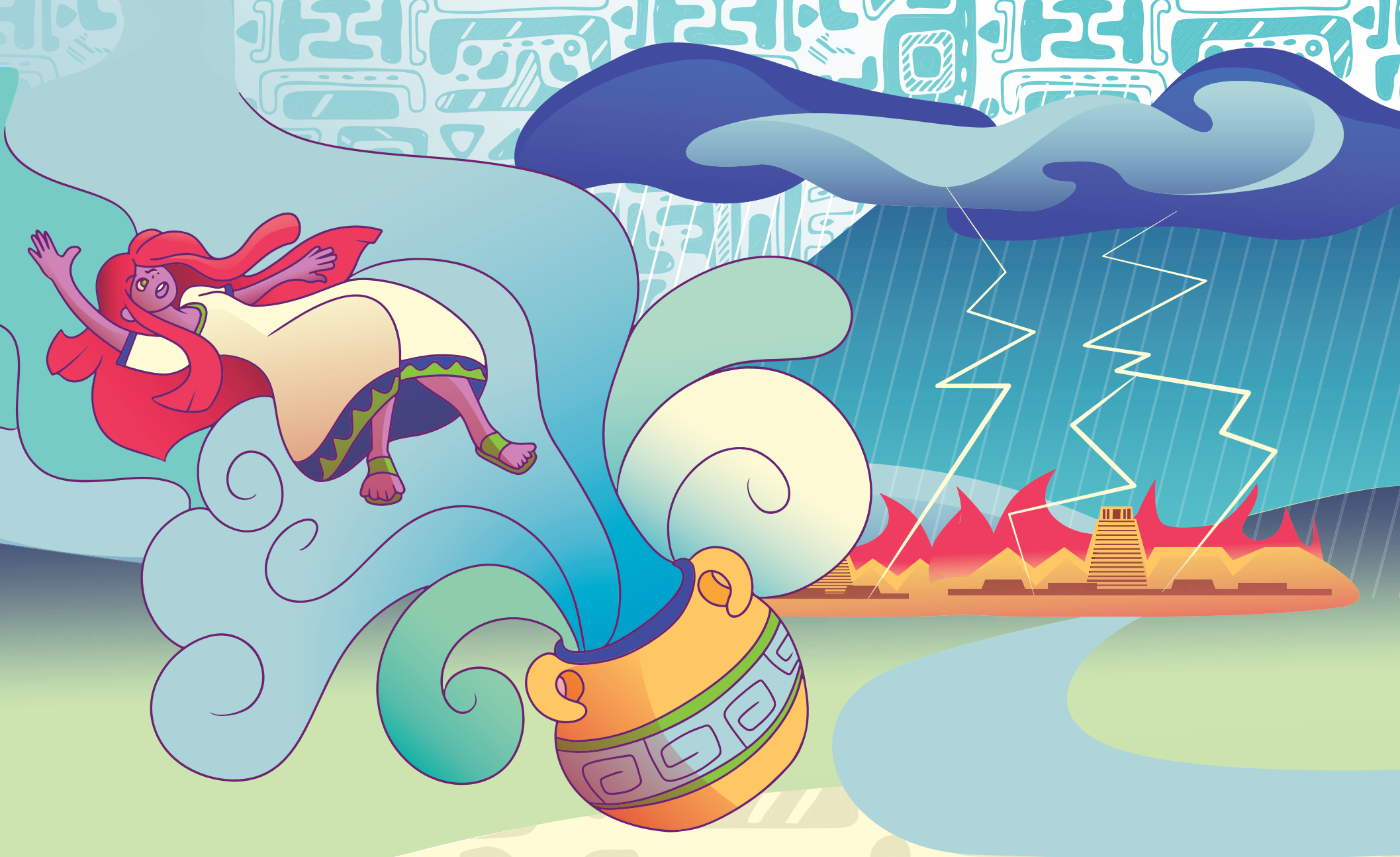

curecieron y, antes de ver relámpago alguno, fue atrapada por un remolino de lluvia que la hizo desaparecer. La buscaron días enteros. Los padres preguntaron a todos en el pueblo si alguien la había visto, pero nadie dio razón de ella. Después de la fuerte tormenta, la joven despertó en un extraño y frío lugar. Era una gran cueva blanca con enormes rocas rodeadas de charcos de agua dulce y cristalina. Cuando se disponía a averiguar en dónde se encontraba, escuchó un fuerte tronido, como si algunas de esas rocas hubieran chocado. - Niña - dijo un hombre grande y misterioso- ¿sabes por qué estás aquí? Ella no respondió. -Escucha bien lo que vas a hacer - dijo con un tono autoritarioEn esos recipientes de roca que están por allá encontrarás tomates, frijoles, chiles y maíz y todo lo necesario para que me hagas de comer. Me iré a trabajar, más te vale que cuando regrese esté lista la comida, no se te olvide, quiero grandes tortillas, ¿me oíste? El enorme hombre se preparó para partir, pero antes de marcharse tomó de las rocas extraños objetos que guardó en su morral. Cuando la joven comenzó a cocinar, creyó escuchar voces en el interior de unos recipientes. Sintió curiosidad por saber quién era, así que escaló hasta el contenedor más grande y con gran esfuerzo movió las enormes losas que servían como tapa. Sorprendida, observó que de uno brotaban nubes. Notó que en otros había agua o bolitas de granizo, pero al abrir la de los truenos y relámpagos, éstos salieron huyendo. Fue entonces que el hombre, quien en realidad era el señor de la lluvia, se dio cuenta de la tormenta que escapaba de su casa. La joven se asustó cuando vio que el agua se desbordaba. Intentó detenerla, pero esta no dejaba de salir de la cueva. Se arrepintió de no haber hecho lo que

se le había ordenado, pues cuando llegó a la puerta, vio desde las alturas cómo se destruía su pueblo, donde muchos murieron. Aún empapada en lágrimas, volvió a escuchar la suave voz del viento que le susurraba que se escaparan juntos, porque el señor de la lluvia la castigaría a su regreso. Con preocupación, la joven destapó la roca y liberó al viento, que de inmediato la abrazó, la consoló y se la llevó volando por los cielos.

\section{Se dice que ese día el viento la puso a} salvo y le advirtió que no malgastara el agua. pues esta podría volar a Las nubes y decirle al señor de La Lluvia dónde estaba su escondite. 


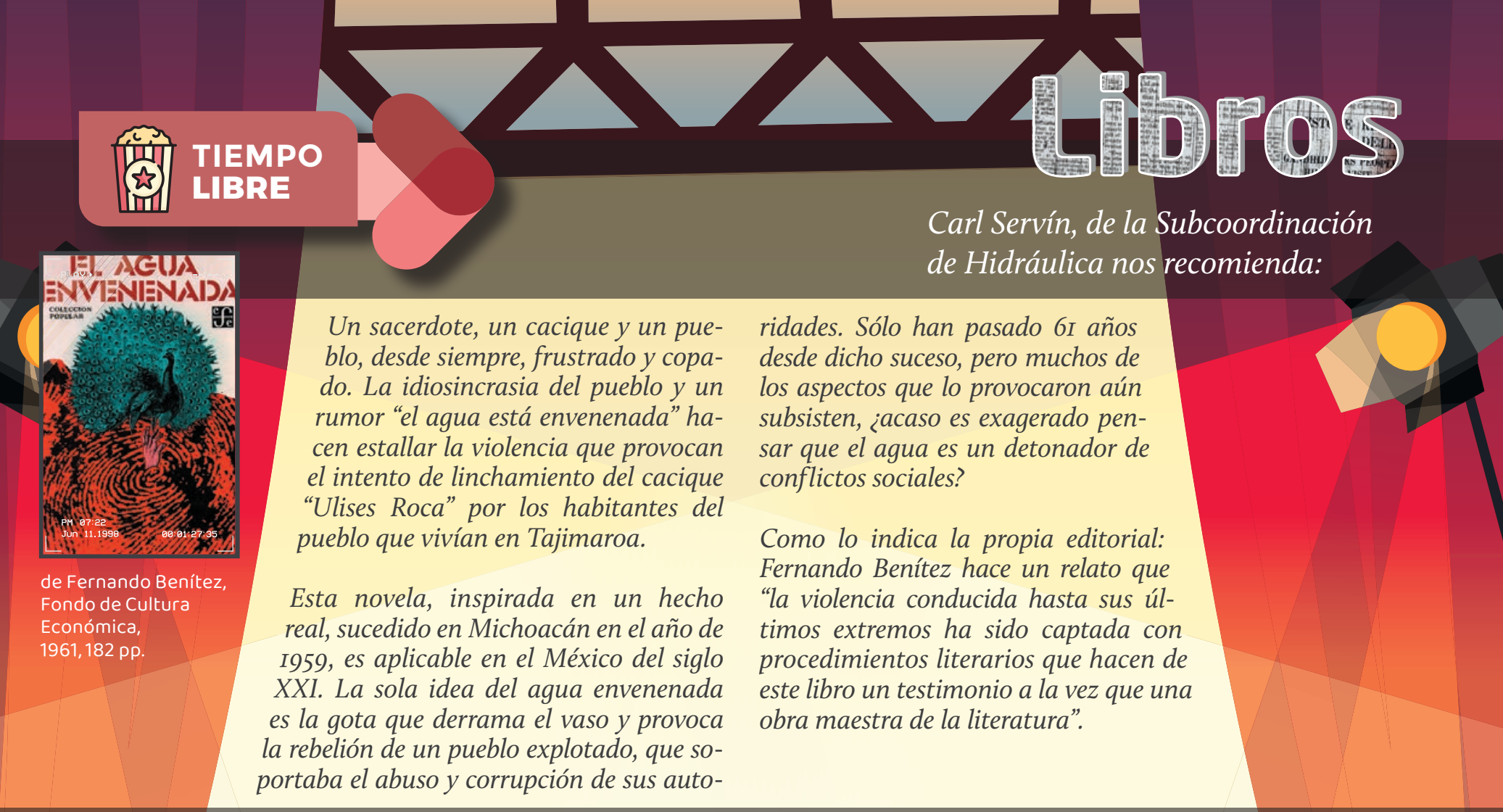

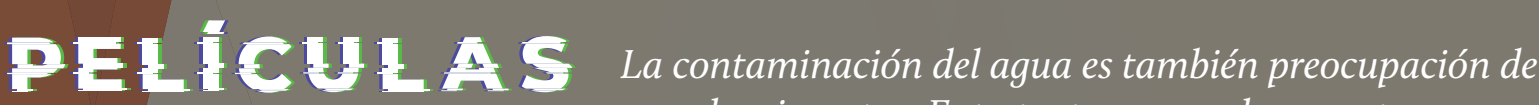 Y SERIES grandes cineastas. Entretente y aprende con estas exce- lentes propuestas disponibles en Netflix:}

Inspirada en hechos reales, narrados inicialente en un artículo publicado en The New York

Times en 20I6, esta película cuenta la historia de cómo un abogado investiga varias muertes inexplicables en Virginia Occidental y descubre que estas están ligadas al ácido perfluorooctanoico (APFOA), empleado en la fabricación de teflón para sartenes antiadherentes. Cientos de galones de lodo tóxico habían sido arrojados a un río por la compañía productora. La historia se convierte en noticia nacional, lo cual da origen a una revisión científica independiente que confirma la toxicidad del APFOA. El abogado no descansará hasta ver que se haga justicia a todas las víctimas de este irresponsable acto de contaminación. Mark Ruffalo y Anne Hathaway estelarizan este drama que no puedes dejar de ver.

Documental que explora nuevas tecnologías que tienen el potencial de resolver la crisis mundial del agua. En él se destacan avances científicos y tecnológicos que se han estado dando, a menudo fuera de los reflectores, para que la población mundial tenga acceso a agua limpia y a servicios de saneamiento y se proteja el medio ambiente. Narrado por Liam Neeson, cuenta con la participación de destacados científicos, ingenieros y activistas de todo el mundo, incluido Matt Damon, cofundador de la ONG Water.org, así como Jaden Smith, cofundadora de 501 CThree, organización sin fines de lucro que provee de sistemas de filtración a comunidades en Flint, Michigan, EUA.

En 2016, el poblado de Flint, Michigan, EUA, llamó la atención del mundo entero al descubrirse niveles alarmantes de plomo en su red de suministro de agua por la falta de anticorrosivos en las tuberías, envenenando a la población con este metal. Además, por falta de una adecuada cloración se propician enfermedades graves, tales como la legionelosis. Esta docuserie revela que las causas fueron negligencia, corrupción y conspiración. A causa de ello, en plena campaña electoral por la presidencia y autoridades locales, se desatan olas de violencia e ingobernabilidad por falta de confianza en los políticos. Un cuerpo de policía disminuido y con poco presupuesto resulta insuficiente para combatirlas y proteger a la ciudad.

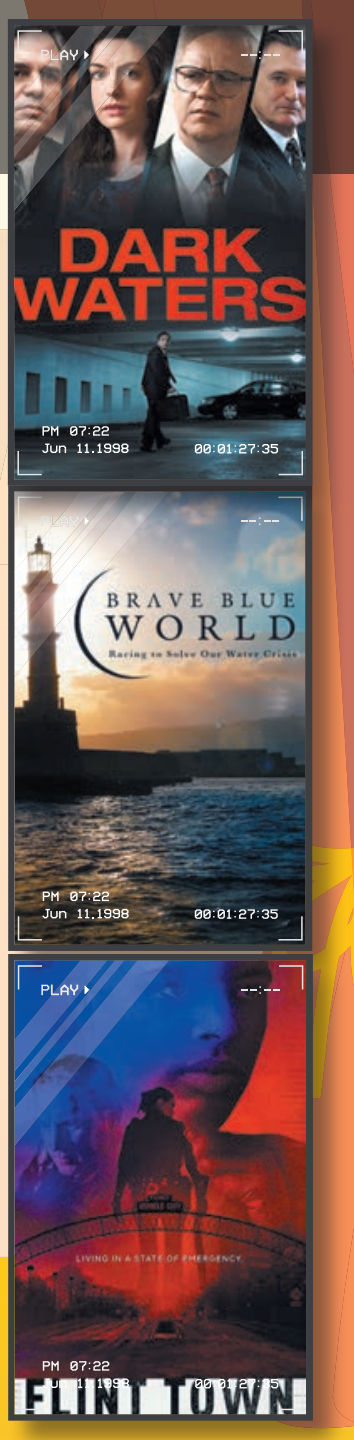


